\title{
Corporate Social Responsibility (CSR) in India: A Review
}

Mr. Neelmani Jaysawal ${ }^{\dagger}$ and Mrs. Sudeshna Saha ${ }^{\breve{ }}$

Abstract

Corporate Social Responsibility (CSR) is a concept, which states that private corporation or public organisation has a responsibility to the society they belong to. It minimises the cost as well as risks, thereby, increasing the brand value and reputation of the company. According to Howard Bowen (pp. 3), "CSR refers to the obligations of businessmen to pursue those policies to make those decisions or to follow those lines of relations which are desirable in terms of the objectives and values of our society." The CSR activities need to be in tune with effective strategic policies so that the aim of sustainable environmental, social and economic progress may be achieved. This article seeks to explain various initiatives taken in the field of CSR by the different companies of India. In doing so, it discusses the growth and the key challenges faced while trying to deliver the activities of CSR.

Key words: Social Responsibility, Strategic Policies, CSR, Community Volunteering, Economic Progress, India

\footnotetext{
${ }^{+}$Assistant Professor, Department of Social Work, Visva-Bharati, PO-Sriniketan, Distt.-Birbhum (West Bengal), India, Pin-731236, email:neelmanijayswal@gmail.com

`́ Assistant Professor, Department of Social Work, Visva-Bharati, PO-Sriniketan, Distt.-Birbhum (West Bengal), India, Pin-731236, email: sudeshnasaha1@gmail.com

(C) 2015 Jaysawal and Saha. This is an Open Access article distributed under the terms of the Creative Commons Attribution License (http://creativecommons.org/licenses/by/2.0), which permits unrestricted use, distribution, and reproduction in any medium, provided the original work is properly cited.
} 


\section{Introduction}

Corporate Social Responsibility (CSR) is a term, which has attracted the attention of social science academicians very recently. It has a long tradition (perhaps since the late 1800s) of corporate philanthropy. In India, Tata has been implementing CSR activities since 1912. In similar fashions, vocational and technical training have been laid on to develop the under-developed sections of the society by various business houses across the country. William C. Frederick (2006: 20) defines "social responsibilities [as a way, where the] ...businessmen should oversee the operation of an economic system that fulfils the expectations of the public. And this means in turn that the economy's means of production should be employed in such a way that production and distribution should enhance total socio-economic welfare". Earlier in 1975, S.P. Sethi coined the term as 'corporate social performance', which was revisited and developed by A.B. Carrol (1979) and has been further refined by S.L. Wartick and P.L. Cochran in 1985. According to Sethi, the corporate social performance has been classified between various actors like social obligation, social responsibility and social responsiveness (Prabhakar and Mishra, 2013). With the emergence of globalisation, CSR has emerged as a key player. India being a developing country bears enormous potential for CSR. It may assist her in developing sustainable livelihood options. Even Gandhijee focused on the need for moral leadership and social responsibility. Speaking at the Indian Merchants' Chamber, he had said - "[i]ndustry and trade have to discharge many responsibilities to the community" (Gupta, 2013: 179).

The paradigm of the concept of CSR has shifted in the last twenty years because of triangular relationships between the companies, state and the society. In the current time, the companies can never remain isolated from the interests of the common people. The companies are realizing the fact that business practices may have to deviate from the normal practice of solely focusing on profits into the public goodwill (Raynard and Forstater, 2002). Due to the liberalisation phase, the private entities are expanding across the boundaries. However, this intervention requires a collaborative effort between the private entities and the government. The state needs to be in a position to safeguard the interests of the common people, which may ultimately result in promotion of CSR activities in consonance with their demands. This is also to derive that companies need to gain a space among the community members through addressing socio-economic concerns of the people. Even the masses prefer to associate with those private entities in terms of business transactions, which invest in the upliftment of community welfare. All private corporations are beginning to capture social capital through expansion of their CSR activities around the world.

The article begins with the discussion of the concept of corporate social responsibility followed by the rationale and constitutional status of CSR in India. It will then discuss the growth and challenges faced by CSR in India.

\section{Corporate Social Responsibility (CSR) - A Concept}

CSR is a comprehensive set of policies, practices and programmes that are integrated into business operations, supply chains and decision-making processes throughout the organisation. It addresses various concerns of society like legal, ethical, commercial associated with business practices and brings equilibrium between expectation of society and profit motive of business houses. The main goal of effective CSR is to achieve commercial success in ways, which honours ethical values, and respect natural environment. Therefore, it consists of business ethics, corporate citizenship, corporate accountability, sustainability and corporate responsibility. As per the United Nations and the European Commission, CSR leads to 'triple bottom line'profits, protection of the environment and fight 
for social justice (Mathur and Midha, 2012). World Business Council for sustained development states that CSR is "the continuing commitment by business to behave ethically and contribute to economic development while improving the quality of life of the workforce and their families as well as of the local community and society at large" (Garg, 2014). Indeed, it is a form of corporate self-regulation integrated into a business model. It functions as an inbuilt self-regulating mechanism whereby business monitors ensures its active compliance with the spirit of law (Garg, 2014). The goal of CSR is to embrace the responsibility for the company's actions and encourage a positive impact through its activities on environment and communities (Garg, 2014). It is an agglomeration of public interest with private profit. Having commented on it, the Canadian Centre for Philanthropy states that CSR is a set of management practices, which ensures that the company minimises the negative impact of its operations on society while maximising its positive impact (Garg, 2014). The CSR reaffirms the views that business is an integral part of society and keeps a pivotal role in sustenance and improvement of sustainable development. CSR is not a mere philanthropy but comprises voluntary intervention into the arena of welfare approach. In doing so, CSR aims to attract socially responsible in the form of providing public good in conjunction with business strategies (Uvais and Cholasseri, 2013). CSR strategies may thus be used to create sustainable competitive advantage firm (Uvais and Cholasseri, 2013).This is because CSR is indicative of self-serving behaviour on the part of managers (Uvais and Cholasseri 2013), which encompasses the economic, legal, ethical and discretionary expectations that society has on organisations at a given point of time (Gautam and Singh, 2010). Bebbington uses the term 'CSR reporting' which establishes the link between reporting function and organisational function (Gautam and Singh 2010).

\section{Rationale for CSR Activities}

Each organisation has two aspects - first, its profit orientation, and the second, its association with social indicators. The business motive can be infinite only when its share into social welfare seconds it. The inclusive growth of community has the potential to increase the client base for a particular organisation. The mushrooming growth of an organisation is very much dependent upon the satisfaction of the community with its client base. A society has numerous dimensions of adversity ranging from economic to socio-cultural upheavals. The sudden encroachment of an external actor over the community may lead to its devastation. Therefore, the active involvement of existing business houses may safeguard the interest of society from both internal economic aggression and external encroachments. The scope of participation of local people in the welfare programmes initiated by private entities may lead to harmony between profit motives and social welfare. The broad rationale for CSR is based on a common philosophy, which states that an organisation's social responsibility arises from the fact that a business enterprise derives several benefits from society, which requires the enterprise to provide returns to society as well. A business cannot be successful in a society, which fails. In modern times, customers are unlikely to be swayed by mere product satisfaction but expect sociallyresponsible behaviour of the private entities also. In their view, the ethical standard of the company in congruence with mass welfare keeps an important position in the way of its growth. Therefore, CSR plays an important role in justifying its business motives apart from contributing towards social welfare. The scale and nature of the benefits of CSR for an organisation can vary depending on the nature of the enterprise, and are difficult to quantify, though there is a large body of literature exhorting business to adopt measures beyond financial ones (Garg, 2013). CSR is titled to aid an organisation's mission as well as a guide to what the company stands for and will uphold to its consumers (Garg, 2013). Many companies use the strategy of benchmarking to compete within their respective industries in CSR policy, implementation, and effectiveness (Garg, 2013). It may improve even perception of 
company towards their staff by engaging them in community volunteering work (Garg, 2013). It also encourages customer orientation among employees. More importantly, in this age of widespread communication and growing emphasis on transparency, clients and employees are supposed to prosper reputation of organisation based on its ethical and social inclination. Therefore, CSR activities assist the organisation in widening its mass base. It leads to good public image, which in turn may improve the business of private or public organisation. As long as consumers are aware about social impact of their private organisation, they become attracted towards it. Many potential clients who themselves operate CSR activities expect their suppliers to do some kinds of developmental activities. The implementation of CSR programmes in an organisation insulates the organisation from risks of social mistrust.

\section{Constitutional Status of CSR in India}

The Companies Act, 2013 is an historic milestone in the area of growth of CSR. It provides an opportunity to corporate sector to socialise its business operations. The 2013 Act has introduced several provisions, which would change the way Indian corporates do business, and one such provision is spending on CSR activities

(http://gtw3.grantthornton.in/assets/Compani es_Act-CSR.pdf). Thus, CSR, which has largely been voluntary contribution by corporates, has now been included in law. The Section 135 of this Act states that every company having net worth of ₹50 million or more, or turnover of ₹100 million or more, net profit of ₹50 million or more during any financial year, shall require establishing one full-fledged CSR board (http://gtw3.grantthornton.in/assets/Compani es_Act-CSR.pdf). Even in terms of the constitution of the board, the CSR provisions under the 2013 Act requires a minimum of three directors for the constitution of the CSR committee

(http://gtw3.grantthornton.in/assets/Compani es_Act-CSR.pdf). As per schedule VII of the Act, the activities of intervention under CSR project are environment sustainability, empowering women and promoting gender equality, education, poverty reduction and eradicating hunger, social business projects, reducing child mortality and improving maternal health, improvement of health, imparting of vocational skills, contribution towards central and state government funds for socio-economic development and relief, etc.

\section{Growth of CSR in India}

CSR in India has been quite old. In ancient times, it used to be called as charity in the name of "daan". During the Gupta period (320 to $550 \mathrm{CE}$ ), the philanthropy was at its peak where the emperor used to donate a major chunk of treasury for the welfare of the common people. Philosophers such as Kautilya from India and pre-Christian era philosophers in the West preached and promoted ethical principles while doing business. Even during the Mughal period, the concept of philanthropy received its promotion under the reign of Akbar. This scenario continued during the British period also. In the pre-industrialisation period, which lasted until 1850, wealthy merchants shared a part of their wealth with the wider society by way of setting up temples for a religious cause (Garg, 2014). However, the beginning of the 19th century transformed this concept of philanthropy and encouraged the industrialists to empower communities through different capacity-building programmes. The industrial families of the 19th century had a strong inclination toward charity and other social considerations. Prominent business houses of India like Tata, Birla, Godrej and Singhania industries changed the way philanthropy used to be seen. Influenced by Gandhijee's views of Trusteeship, these entrepreneurs turned their attention towards building knowledge capital in the country. His view of the ownership of capital was one of trusteeship, motivated by the belief that essentially society was providing capitalists with an opportunity to manage resources that should really be seen as a form of trusteeship on behalf of society in general. Therefore, the major chunk of their profit was utilised in 
developing indigenous human resources and inclining their clients towards upgrading their status in the society. The independence of our country broadened its scope and witnessed participation of even public sector undertakings in CSR. The public sector was seen as the prime mover of development. The nomenclature of CSR got into existence in India in the early 1970s. In 1965, Indian academicians, politicians and businesspersons set up a national workshop on CSR aimed at reconciliation. They emphasised upon transparency, social accountability and regular stakeholder dialogues (Garg, 2014). Furthermore, the emergence of liberalisation policy in India led to relaxation in factories Act and licensing policy, which encouraged the private as well as the public sector organisations to undertake the CSR activities at large scale. Increased growth momentum of the economy helped Indian companies grow rapidly and this made them more willing and able to contribute towards social cause (Garg, 2014). The basic objective of CSR in these days is to maximize the company's overall impact on the society and stakeholders. An increasing number of companies throughout their business operations and processes are comprehensively integrating CSR policies, practices and programs (Garg, 2014). For example, some corporations such as Bharat Petroleum Corporations Limited (BPCL), Maruti Suzuki India Limited, and Hindustan Unilever Limited (HUL) adopt a more comprehensive method of development (Garg, 2014). Provision of improved medical and sanitation facilities, building schools and houses, and empowering the villagers and in process, making them more self-reliant by providing vocational training and a knowledge of business operations are the facilities that these corporations focus on (Garg, 2014). It has been estimated that India has over 200,000 private sector trusts and foundations, a large number of which are set up by Indian business houses and are working towards social causes of mitigating social evils. Companies have CSR teams that devise specific policies, strategies and goals for their CSR programs and set aside budgets to support them. These programs, in many cases, are based on a clearly defined social philosophy or are closely aligned with the companies "business expertise". CSR is not only used for branding but also to curb the hands of regulation (Amaeshi et al., 2007).

\section{Growth of CSR of TATA}

After independence, TATA has broadened its CSR intervention in India. After independence, JRD Tata who always laid a great deal of emphasis to go beyond conducting themselves as honest citizens pointed out that there were many ways in which industrial and business enterprises can contribute to public welfare beyond the scope of their normal activities (Ahmed, 2013). He advised that apart from the obvious one of donating funds to good causes which have been their normal practice for years; they could have used their own financial, managerial and human resources to provide task forces for undertaking direct relief and reconstruction measures (Ahmed, 2013). It has intervened into the area of social welfare of employees. It has focused extensively on education and livelihood security in its intervention areas. They have also participated with the government to improve sanitation in a village called Tiruvidenthai. The Tata Council for Community Initiatives ( $\mathrm{TCCl}$ ) is a unique initiative that lends structure to the Tata group's approach of sustainable development while driving its community engagement and improvement programmes (Uvais and Cholasseri, 2013). The healthcare projects of Tata Steel include facilitation of child education, immunisation and childcare, plantation activities, creation of awareness of AIDS and other healthcare projects. Tata Steel has hosted 12 Lifeline Expresses in association with the Ministry of Railways, Impact India Foundation and the Government of Jharkhand (Srivastva et al., 2012). It has served over 50,000 people. Five thousand people have received surgical facilities and over 1,000 people received aids and appliances (Srivastva et al., 2012). Tata Steel has also covered 42 villages in Gamharia block in Seraikala Kharsawa for promotion of SHGs (Srivastva et al., 2012). In Pune, the TATA Trust is 
collaborating with several NGOs in assisting employees' women dependents in terms of providing medical care, short-stay homes. In the area of educational support, it has initiated a scholarship program called 'Vidyadhanam', which supports 211 students. It has entered into the sector of skill development through upgrading ITI on Public Private Partnership (PPP) model. In Kerala, TATA has set-up Srishti Welfare Centre, which provides education, training and rehabilitation of children and young adults. TATA Steel has been awarded Corporate Social Responsibility Excellence Award in 2010 by Associated Chambers of Commerce \& Industry of India. Even Tata Consultancy Services (TCS) bagged Community Awards for Excellence in Category for Adult Literacy Programme in 2011. It has won a very prestigious award called "Gold Stevie ${ }^{\circledR}$ for CSR" in 2014. In the way of training facilities, the TATA Archery Academy was established in 1996 at Jamshedpur. Even Tata Chemicals Limited established TATA Chemicals Society for Rural Development in 1980 to encourage various social objectives around the communities of Mithapur. It supports sustainable rural development. The initiatives taken by it are agricultural development, animal husbandry, watershed development, education, rural energy, etc. It has intervened even in disaster relief activities. During natural calamities, TATA Relief Committee provides relief in terms of rehabilitation and relief measures. Tata has collaborated with UNDP for developing Tata Index for Sustainable Human Development, which aims at directing, measuring and enhancing community welfare activities initiated by it (Srivastva et al., 2012). Tata Motors has also ventured into the affairs of CSR through establishing two societies in Lucknow - Samaj Vikas Kendra \& Jan Parivar Kalyan Santhan for rural development and for providing healthcare to the rural areas (Srivastva et al., 2012). These societies are engaged with the task of improving health, education and women's empowerment in rural areas. With funding support from the Tata Motors, these societies run the dental check-up and satellite clinics in selected villages by providing all infrastructural facilities and medical expertise.

\section{CSR of Hindustan Petroleum Corporation Limited}

The CSR activities of Hindustan Petroleum Corporation Limited (HPCL) have been based on creating shared value. The underlying principle behind this concept is conglomeration of corporate success and social welfare. The programs of CSR of HPCL are more oriented towards education and healthcare of communities. They cater to not only general mainstream population but disabled children also. In terms of childcare, it has collaborated with Child Rights and You (CRY), an NGO for improving the lives of under-priviledged sections of society. Even a programme called "Muskan (Smile)" aims at providing basic needs like food, clothes, healthcare and vocational training. It also provides time-bound computer training program to students in semi-urban and rural schools. During the year 2011-12, the project was implemented in 30 schools in different parts of India covering 5500 students as beneficiaries of this program. In the same year, another sub-set of CSR program named Nanhi Kali (Girl Child) has covered 9168 female children from Standard I to $X$. The programme provides quality education to girls from economically disadvantaged families through a sponsorship, designed to deliver academic support that empowers them to make a success of their schooling experience, material support including uniforms (www.hindustanpetroleum.com/.../pdf/Bringin g_Smiles_2010-11.pdf). It has also started a project called Navjyot in 2005 in coordination with Navjyoti India Foundation, New Delhi for facilitating the residents of Bawana resettlement colony, Delhi in terms of Child Health and Welfare Program. Furthermore, it intervened into the area of HIV testing also through establishing project Suraksha, which aims at testing of patients for HIV/AIDS. They provide vocational training among youths in developing IT skills, skin care and beauty culture. In terms of livelihood, HPCL has initiated the work in the area of lighting a 
billion lives. Under ADAPT (Abled Disabled All People Together) programme, children with special needs are assisted for in receiving education. In terms of healthcare, it has made provision for testing of truck-drivers for HIV under Suraksha program. It also provides free rural health care services by operating mobile medical units (Priya and Autade, 2013). In terms of skill development, HPCL has initiated Swavalamban, a project, which enables rural youths to be self-employed (Priya and Autade, 2013). In the sustainable model of energy, it has intervened solar lighting- Lighting a Billion Lives - The LaBL program sets up solar charging stations in villages that offer certified, bright, solar lanterns for rental to the local people (Priya and Autade, 2013).

\section{CSR of Gas Authority of India Limited}

The Maharatna PSU of India, Gas Authority of India Limited (GAIL) has contributed towards promotion of education and healthcare for children. GAIL's education-based CSR called 'Padho Aur Badho' (Learn and Advance)' strives to bring some degree of succour to the children living in poverty by fulfilling their dreams of receiving education (http://www.gailonline.com/final_site/pdf/Gail _CSR_14-03-2013.pdf). Being engaged with literacy enhancement programme of GAIL, many children have been benefitted in the area of universal access to quality education. One of its initiatives in the area of innovative education methodology is E-Shiksha programme. This programme has helped in making computer literacy accessible to government schools and facilitated students to accomplish their regular computer school curriculum. Since 2009, this project has been functional in setting up 200 non-formal education centres in the slum areas of Delhi. In the area of empowerment of women, GAIL has collaborated with Infrastructure Leasing and Financial Services (IL \& FS) for multi-skill development. It has provided livelihood opportunities to rural women through selfemployment initiatives. In the Jhabua district of Madhya Pradesh, Anhad Gram is a project that provides skill based training, better technology and market access for the local produce, to provide an alternative and sustainable livelihood. The establishment of District Disability Rehabilitation Centre established by GAIL has been instrumental in taking care of disabled people in the Jhabua district. Better care has been extended to over 500 persons living with disabilities in the form of operative and reconstructive surgeries. GAIL's project Aarogya (healthy state) is a unique programme wherein Mobile Medical Units (MMU) travel door to door for providing basic healthcare services covering awareness, diagnosis and cure in the remote areas of Pata and Vijaipur. It aims to roll out 1,000 MMUs in rural India to reach out to 25 million Indians by 2017 (http://www.gailonline.com/final_site/pdf/Gail _CSR_14-03-2013.pdf).

\section{CSR of Steel Authority of India Limited}

Steel Authority of India Limited (SAIL) has been contributing towards the development of society through various community welfare programs. It has provided access to nearly 7.3 million people across 435 villages by constructing roads and ensuring availability of water resources to 3.9 million people (http://saiindia.gov.in/english/home/our_prod ucts/audit_report/Government_Wise/union_au dit/recent_reports/union_performance/2010_2 011/Commercial/Report_no_27/chap6.pdf).

SAIL has adopted 79 villages in eight states for comprehensive development as Model Steel Villages. In 2008-09, it has opened 138 schools for providing education to 73,925 students. It has set-up health centres to provide medical care to the poor and needy persons. Between 2007-08 and 2008-09, $10 \mathrm{MMU}$ were provided. SAIL has organised nearly 5989 medical camps and treated 1.75 million patients during 200910. During 2006-10, it has provided financial assistance of worth ₹50 million for facilitating education to 47,718 students. SAIL has also set up six special schools exclusively for the poor, underprivileged, below poverty line (BPL) children at its five integrated steel plant locations covering around 1,400 children providing free education, midday meals, uniform, including shoes, textbooks, stationery 
items, school bag, water bottles, etc. SAIL has contributed immensely to the economic development of its peripheral areas. Peripheral development means growth of grass-root level people in the areas of education, healthcare, drinking water, women's upliftment, employment generation and other associated activities. Under peripheral development, various activities are being undertaken around the plants/units up to a radius of $16 \mathrm{kms}$. It is making special efforts to initiate new projects in the area of road connectivity, construction of bridges/culverts, and access to improved water sources. In terms of water availability, it has provided access to drinking water to 3.9 million people through installation of 5,153 water sources in India. In terms of education, SAIL has established about 146 schools in its steel townships to impart modern education to more than 69,000 children. It has also established 54 primary health centres, 12 reproductive and child health ( $\mathrm{RCH}$ ) centres, 17 hospitals and 7 super-specialty hospitals to provide modern health care to more than 30.60 million people.

\section{CSR of Indian Oil Corporation Limited}

At Indian Oil Corporation Limited, CSR practices have been running since 1964 . The CSR activities are run under the major framework of community development, which consists of education, healthcare, drinking water and sanitation as well as empowerment of marginalised women and depressed classes (Priya and Autade, 2013). In Mathura, Uttar Pradesh, the IOCL has established 50-bed Swarna Jayanti Samudaik hospital. For comprehensive healthcare of existing community of project area, it has founded Assam Oil School of Nursing at Digboi, Assam in 1986. Another landmark progress has been achieved in the area of setting up Indian Oil Rural Mobile Health Care Scheme whereby qualified doctors treat poor patients for even critical diseases (Priya and Autade, 2013). Apart from the health sector, IOCL has progressed towards education sector also. The IOCL has made the provision for a total of 600 scholarships under which ₹3000 is awarded to the students of engineering and medical backgrounds per month for 4 years (Priya and Autade, 2013). Even for skill enhancement, it has made provision for merit scholarship to Industrial Training Institutes (ITI) students (Priya and Autade, 2013).

\section{CSR of Oil and Natural Gas Commission}

Oil and Natural Gas Commission (ONGC) has taken various initiatives in terms of carrying out CSR activities. It has ventured into various sectors like education, employment, environment protection, rural development and eradication of poverty. It is offering merit scholarship to the students pursuing graduation and master degree in different universities of India (Das and Halder, 2011). It has spent nearly ₹42 million in the year 2004-05 and 2005-06 on health care, drinking water scheme and medical camps (Das and Halder, 2011). Until March 2009, 300 power tillers had been provided to different SHGs in Assam under special Swarnajayanti Gram Swarozgar Yojana (SGRY) through credit linkage from nationalized banks with the help of State Institute of Rural Development (SIRD) (Das and Halder, 2011). In terms of employment activity, ONGC has contributed ₹0.7 million to the Centre for Rural Development (CRD) for the innovative project "Rickshaw Bank Gauhati". Under this project, it provides rickshaws to participating pullers. It concurrently organises health awareness camps and further extends the mass consciousness for health and hygiene. In Sibsagar, Assam, ONGC has supported various Self-Help Groups (SHGs). It has provided nearly 50 percent subsidy in power tillers. Under Yuva Samridhi project, it has created self-employment opportunities in Sibsagar district. In coordination with HelpAge India, ONGC has continued its efforts for facilitating healthcare at the doorsteps of the elderly people through MMUs (http://www.ongcindia.com/wps/wcm/connect /ongcindia/Home/CSR/). In 2011-12, all the 20 MMUs were launched and almost 0.19 million were provided across the eight states and one Union Territory of India (http://www.ongcindia.com/wps/wcm/connect /ongcindia/Home/CSR/). It has also started empowering female tribal population through 
on-the-job training in the improvised looms in Assam. It is fully supporting a project known as "Aakha" the Boat of hope - the mobile medical ships for tribals living in the Majuli Island in Assam. It also supported Shankar Nethralaya, Guwahati for up gradation of diagnostic services (http://www.ongcindia.com/wps/wcm/connect /ongcindia/Home/CSR/). ONGC has contributed Rs.0.7 million to Centre for Rural development (CRD) for the innovative project "Rickshaw Bank Guwahati". Under this project, it provides rickshaws to participating pullers (http://www.ongcindia.com/wps/wcm/connect /ongcindia/Home/CSR/).

\section{CSR of Balmer Lawrie \& Co. Ltd}

This Mini-Ratna PSU of Central Government has also worked intensively in terms of benefiting the community. It is based on financial assistance to certain target groups. Under "Family Home Sponsorship", it sponsors two financially weak families of Kolkata and one in Vishakhapatnam

(http://www.csr.tiss.edu/research/BalmerLawri eEvaluationreport201213.pdf). In terms of education-based scholarship, it has benefited nearly 75 students. Even in the skill-building sector, this CSR has initiated a project called Sambal for vocational training of girls in tourism

(http://www.csr.tiss.edu/research/BalmerLawri eEvaluationreport201213.pdf). Balmer Lawrie sponsored ₹3.7 million in the year 2011-2012 for this project, benefiting 104 girls from all over India. It has supported in building infrastructure for 2400 schools in West Bengal. Apart from education, this PSU has strengthened the health sector too through reducing infant mortality rate (IMR). 12,000 beneficiaries include mothers and children (aged 0-5 years) are being benefitted every year under its healthcare (http://www.balmerlawrie.com/pages/csr). In Silvassa and Sunderban, the PSU has ensured availability of sanitation facilities. It has supported Akshaya Patra to procure kitchen equipment \& a van for mid-day meal distribution in some schools in New Delhi.

\section{CSR of Reliance Industries}

The contribution of Reliance industries in CSR activities has been immense. It has extensively worked in the area of children's education. Its CSR team provides uniforms and books to the students of the neighboring villages around its manufacturing locations. The Dhirubhai Ambani Protsaham Scheme provides financial aid to the toppers, who aim to pursue higher education in medical stream or engineering. Until now, 656 students have received this support. In addition, another initiative called Mumbai Indians Education for All (MIEFA) that began in 2010 has invited until now nearly 700 children from various NGOs to watch the Mumbai Indians play cricket (http://www.ril.com/html/aboutus/social_resp _comm_dev.html). In addition, this MIEFA has provided education to over 70,000 underprivileged children - many of whom dropped out of school earlier for various reasons. Apart from education, health issues have also been key areas of intervention by its CSR - it has developed community medical centres near most of its manufacturing divisions to provide comprehensive health services covering preventive, promotive and curative healthcare services to the community from neighbouring villages (http://www.ril.com/html/aboutus/social_resp_c omm_dev.html).

Another unique joint initiative of RIL and National Association of Blind called Project Drishti has undertaken over 9,000 free corneal graft surgeries for the visually challenged Indians from the underprivileged segment of the society. Under the health sector, they have expanded even for coverage of patients suffering from HIV/AIDS and TB. Hazira Manufacturing Division along with an NGO have launched an orthopedic hospital with ultra-modern facilities and one rehabilitation centre at Nagothane Manufacturing division. Visualising environmental concerns, Reliance industries have ventured into solid waste management too. It has assisted in building a 900-metre road using $5 \%$ plastic waste in various locations of Gujarat. Furthermore, for 
the development of rural infrastructure, it has undertaken 797 works in 760 beneficiary villages of 125 talukas in Gujarat. Continuing with the services and keeping up the tradition, Hazira, Vadodra, Nagothane, Gadimoga and many other manufacturing divisions offer training programmes through various SHGs, thereby, helping the rural women and the youths to be "self-sustaining" and generating income for themselves and supporting their families. It has also initiated work in the area of construction of community halls, burial ground. RIL continues to support the social, educational, cultural and spiritual activities of Shardapeeth of Jagadguru Shankaracharyaji, Dwarka. In terms of ensuring availability of water to the rural areas of Gujarat, it has extended financial assistance to Swajaldhara Scheme organised by Water and Sanitation Management Organization (WASMO), Government of Gujarat, for developing drinking water facility by laying pipeline in the neighbouring villages.

\section{Challenges of CSR in India}

Despite several benefits, CSR in India has suffered from various obstacles in the form of challenges. CSR is not only about reducing the negative consequences of companies' activities, but about the manner in which company can take part in a society in a meaningful way (Jonker and de Witte, 2006). In India, it is seen as a weapon for social activities. While some other academicians argue that, the government does away with their role of playing a regulatory body over powerful business houses. It is also argued that CSR initiatives undertaken result into deviation from basic business roles. The main challenge is to use the capabilities and competences of the company to address social and environmental concerns while at the same time continuing to operate successfully in the traditional business sense (Jonker and de Witte, 2006). Therefore, the CSR practices have been judged from various points of view. One section of society opposes the CSR activities while other one supports its growth. In India, the biggest problem of CSR is the lack of budget allocation followed by lack of awareness among the people towards its true nomenclature.
Smaller enterprises do not take adequate interest in CSR activities and thereby, fail to promote the same. Hence, some of the significant challenges are as follows:-

\section{Absence of Inclination of Community towards CSR Activities}

The general apathy of the community towards CSR initiatives of enterprises also leads to its slow growth. Due to lack of mass awareness, people are kept outside the boundary of CSR. Very little efforts are being made to spread CSR within the local communities and instil confidence in the people (Gupta, 2014). The communication gap between the organisation and the grassroots people have been leading to its discontinued existence. The grassroots people remain unaware of imminent benefits of CSR programs, which further discourages their involvement either at the planning or execution stages.

\section{Lack of Skill in Execution of CSR}

The successful implementation of CSR requires efficiency in its management. Unfortunately, the deficiency of skill among organisational worker leads to ineffective handling of CSR. This initiative also leads to unequal access of benefits of CSR to communities. The paucity of technical and managerial capacity of various corporate sector employees leads to faulty expansion of CSR project in the community.

\section{Absence of Transparency and Accountability}

The lack of transparency among manager of CSR projects leads to unequal distribution of CSR benefits among the masses. This perceived lack of transparency has a negative impact on the process of trust building between the companies and the local communities, which are keys to the success of any CSR initiative (Gupta, 2014). They do not make adequate efforts to disclose information on their programmes, audit issues, impact assessment and utilisation of funds (Gupta, 2014).

\section{Non-consensual Existence of Local Agencies in CSR Projects}

The lack of consensus among local agencies over implementation of CSR projects is also one 
of the important reasons behind its failure. Furthermore, it results into unhealthy competitiveness among the local organisations and limits its abilities to undertake impact assessment of its initiatives from time to time (Gupta, 2014). This lack of consensus often results in duplication of activities by corporate houses in areas of their interventions.

\section{Lack of Consultation Process}

One of the major challenges of CSR is paucity of consultation process. While implementing CSR projects, the organisations have very less interaction with grass-roots level agencies. It works more on top-down approach where the upper authority has more vertical functions. On vertical lines, it does not percolate in the development discourse. Therefore, CSR has been affected by a huge paucity of wide consultation among worker as well as its subjects.

\section{Lack of Dissemination of Progress of CSR}

In the area of CSR, there has been very less dissemination of information regarding progress of CSR. Even if many works continue yet, its effect over society are still not projected. The presentation of CSR progress is done within very close boundaries of the concerned organisation. The existing community is completely unaware about its potential benefits as well as further expansion.

\section{Absence of Regulatory Framework of CSR}

The CSR practice in India had been unregulated until Company's bill' 2012 was passed in 2013. There were no statutory guidelines for regulating the CSR framework in India. Still, there is a lack of regulatory mechanism for governing expansion of CSR projects in India. Although the Company's Act prescribes certain financial limit for expenses on CSR, yet, the absence of the governing body on CSR leads to unregulated allocation of CSR projects by several companies.

\section{Narrow Perception about CSR}

Non-governmental organisations (NGOs) and Government agencies usually possess a narrow outlook towards the CSR initiatives of the companies, often defining CSR initiatives more as donor-driven. As a result, corporates find it hard to decide whether they should participate in such activities at all in the medium and in the long run. Until recently, however, in the interface between "society" and "business", Corporate Social Responsibility (CSR) was manifested as "philanthropy". With successive changes in the business and societal environments, and a better understanding among the stakeholders, 'philanthropy' has evolved into more of "business strategy" (Gupta, 2014).

\section{Unilateral Decision-making}

The CSR implementation in India has been arbitrary in its nature. All major decisions related to CSR are taken within closed boundary of financial incumbents of respective companies without involving community-based stakeholders of the project. Therefore, the expected deliverables of CSR is judged on the lines of profit and loss rather than on the impact over the community. Furthermore, this process leads to uni-dimensional growth of CSR. It keeps on addressing issues of similar nature everyday overlapping current demand of community. This decision-making process results into perception of CSR before community just mere eyewash.

\section{Conclusion}

CSR has proved to be an important landmark in the arena of peaceful co-existence of business and society. On one hand, industrial houses have garnered public support through their developmental intervention, on the other, common people have actively supported these enterprises visualising its transcendental nature. The image of the organisation has been improved. The further statutory provision has made CSR obligatory for all the industries and regulated its expansion so that the ultimate objective may be fulfilled. The case for demonstrating corporate responsibility is getting stronger as expectations among key opinion former, customer and the public are increasing. Therefore, the proposition that CSR is mere eyewash is, in itself, a myth. 


\section{References}

Ahmed, Mohammad Khalil (2013): Corporate Social Responsibility in Indian Organizations, International Journal of Social Economics, 34, pp. 637-663, (excerpted on 22-02-2015 from http://www.mmbgims.com/docs/full_paper/13 _MOHAMMAD\%20KHALIL\%20AHMED_pp.pdf ).

Alejandro Milcíades Peña \& Thomas Richard Davies (2014) Globalization from Above? Corporate Social Responsibility, the Workers' Party and the Origins of the World Social Forum, New Political Economy, Routledge, 19(2), pp. 258-281, (excerpted on 14-02-2015 from http://dx.doi.org/10.1080/13563467.2013.779 651).

Amaeshi, Kenneth M., Abel E. Ezeoha, Bongo C. Adi, PhD, and Manson Nwafor (2007): Financial Exclusion and Strategic Corporate Social Responsibility: A Missing Link in Sustainable Finance Discourse, (ICCSR Research Paper Series no. 49), International Centre for Corporate Social Responsibility, Nottingham University, U.K.

Carrol, Archie B. (1979). A Three-Dimensional Conceptual Model of Corporate Performance, The Academy of Management Review , 4 (4), 497-505.

Das, Bidhu Kanti and P.K Halder (2011): Corporate Social Responsibility Initiatives of Oils PSUs in Assam: A Case Study of ONGC, Management Convergence, 2(2) (excerpted on 17-02-2015 from www.inflibnet.ac.in/ojs/index.php/MC/article/ download/1269/1147).

Frederick, William C. (2006). Corporation, Be Good: The Story of Corporate Social Responsibility, Indiana Polis: Dog Ear Publishing.

GAIL (2013): Corporate Social Responsibility Initiatives Report, GAIL India Limited, (excerpted on 19-02-2015 from http://www.gailonline.com/final_site/pdf/Gail_ CSR_14-03-2013.pdf).

Garg, Deepak (2013): Corporate Social Responsibility and Its Effectiveness in India,
International Journal of Research in Economics \& Social Sciences, 3(11) (excerpted on 16-022015 from

http://www.ijesi.org/papers/Vol\%282\%293\%20 \%28Version-4\%29/D232732.pdf ).

Garg, Girish (2014): Social Impact of Corporate Social Responsibility in India, Radix International journal of banking, finance and accounting, 3(1) (excerpted on 15-02-2015 from rierc.org/banking/paper111.pdf).

Gautam, Richa and Anju Singh (2010): Corporate Social Responsibility Practices in India: A Study of Top 500 Companies, Global Business and Management Research: An International Journal, 2(1), pp. 41-56, (excerpted on 16-02-2015 from http://www.gbmr.ioksp.com/pdf/Gautam\%20\& \%20Singh,\%202010.pdf ).

Gupta, Ananda Das (2013): Business Ethics: Texts and Cases from the Indian Perspective, New Delhi, Springer (ISBN 978-81-322-1518-9).

Gupta, Ananda Das (2014): Implementing Corporate Social Responsibility in India: Issues and the Beyond, in S. Ray, S. Siva Raju (eds.), Implementing Corporate Social Responsibility, Springer, ISBN: 978-81-322-1652-0(excerpted on 20-02-2015 from http://www.springer.com/cda/content/docum ent/cda_downloaddocument/9788132216520c1.pdf?SGWID=0-0-45-1447705-p175456414 ).

Jayanthi, A. and Chandrasekar (2014):

Corporate Social Responsibility - Issues and Challenges in India, International Journal of Scientific Research and Management, pp. 2532, (excerpted on 19-02-2015 from ijsrm.in/special\%20issue\%202/5\%20ijsrm.pdf).

Jeroen Merk (2009): Jumping Scale and Bridging Space in the Era of Corporate Social

Responsibility: Cross-border Labour Struggles in the Global Garment Industry, Third World Quarterly, 30(3), pp. 599-615 (excerpted on 1402-2015 from http://dx.doi.org/10.1080/0143659090274235 4 ).

Jonker, Jan and Marco de Witte (2006): The Challenge of Organizing and Implementing 
Corporate Social Responsibility, New York, Palgrave MacMillan, ISBN: 9780230625990 (excerpted on 20-02-2015 from

http://www.untagsmd.ac.id/files/Perpustakaan_Digital_1/CORPO RATE\%20SOCIAL\%20RESPONSIBILITY\%20The\%2 0Challenge\%20of\%200rganizing\%20and\%20Im plementing\%20Corporate\%20Social\%20Res.pdf ).

Kanji, Nazneen (2010): Corporate Responsibility and Women's Employment: The Case of Cashew Nuts, Gender \& Development, 12(2), pp. 82-87, (excerpted on 12-02-2015 from http://dx.doi.org/10.1080/1355207041233133 2240).

Madras Sivaraman (2013): Corporate Social Responsibility: Readings and Cases in a Global Context, International Journal of Environmental Studies, 70(4), pp. 675-678 (excerpted on 1202-2015 from http://dx.doi.org/10.1080/00207233.2013.841 036).

M, Uvais and Hafeefa Cholasseri (2013): Corporate Social Responsibility: Dimensions and Challenges in India, International Journal of Engineering Science Invention, 2(3), pp. 27-32, (excerpted on 16-02-2015 from www.ijesi.org/papers/Vol(2)3\%20(Version4)/D232732.pdf).

Mathur, Sanjeela and Aditi Midha (2012): Impact of Corporate Social Responsibility through Cause-related Marketing on Consumer Perception: A Comparison with Traditional Marketing Tools, Gian Jyoti e-journal, 2(3), (excerpted on 21-02-2015 from www.gjimt.ac.in/wpcontent/uploads/2012/12/17_SanjeelaMathur.pdf).

National Corporate Social Responsibility (NCSR) Hub, TISS (n.d): Evaluation of CSR Projects
(2011-2012) of Balmer Lawrie \& Co. Ltd., Mumbai, India (excerpted on 20-02-2015 from www.csr.tiss.edu/research/BalmerLawrieEvalua tionreport201213.pdf ).

Pavlos A. Vlachos, Nikolaos G. Panagopoulos, Aristeidis Theotokis, Ramendra Singh \& Rakesh K. Singh (2014) When Do Corporate Social Responsibility Initiatives Impact on Customerfacing Employees? Evidence from India and the Netherlands, The International Journal of Human Resource Management, 25(22), pp. 3086-3112, (excerpted on 14-02-2015 from http://dx.doi.org/10.1080/09585192.2014.934 $884)$.

Prabhakar, Rajeev and Sonam Mishra (2013): A Study of Corporate Social Responsibility in Indian Organization: An Introspection, Paper presented at 21st International Business Research Conference, organized by Ryerson University, Canada, June 10 - 11, 2013.

Priya, Meenu Shant and Autade Ajay (2013): A Comparative Study on CSR Practices of HPCL and IOCL, International Monthly Refereed Journal of Research in Management \& Technology, 2, (excerpted on 18-02-2015 from http://www.abhinavjournal.com/images/Mana gement_\&_Technology/Feb13/12.pdf).

Raynard, P. and Forstater, M. (2002): Corporate Social Responsibility: Implications for Small and Medium Enterprises in Developing Countries, United Nations Industrial Development Organization, (excerpted on 13-09-2015 from www.unido.org/userfiles/Bethkek/csr.pdf).

Srivastva, Amit Kumar, Gayatri Negi, Vipul Mishra and Shraddha Pandey (2012): Corporate Social Responsibility: A Case Study Of TATA Group, IOSR Journal of Business and Management, 3(5), pp. 17-27, (excerpted on 17-02-2015 from http://iosrjournals.org/iosrjbm/papers/vol3-issue5/D0351727.pdf). 